Jurnal Adat dan Budaya, Vol.1, No.2 Tahun 2019

ISSN: E-ISSN 2615-6156, P-ISSN: 2615-6113

Jurnal Homepage: https://ejournal.undiksha.ac.id/index.php/JABI/index

\title{
MODEL PROJECT BASED LEARNING BERLANDASKAN TRI HITA KARANA BERPENGARUH TERHADAP KOMPETENSI PENGETAHUAN IPS
}

\author{
Gede Billy Bagiarta Sutrisna ${ }^{1}$, I WayanSujana², Ni Nyoman Ganing 3 \\ 123Program Studi Pendidikan Guru Sekolah Dasar, Universitas Pendidikan Ganesha, Bali, Indonesia \\ E-mail: billy.bagiarta.sutrisna@undiksha.ac.id
}

\begin{abstract}
Abstrak
Rendahnya kompetensi pengetahaun IPS siswa akibat kurang aktifnya siswa dalam proses pembelajaran dan kurangnya penggunaan model inovatif oleh guru menjadi alasan penelitian ini dilakukan. Penelitian ini bertujuan untuk mengetahui pengaruh yang signifikan model pembelajaran project based learning berlandaskan tri hita karana terhadap kompetensi pengetahuan IPS siswa. Penelitian ini merupakan Penelitian eksperimen semu (quasi eksperiment) dengan rancangan penelitian menggunakan nonequivalent pretest-posttest control group design. Populasi dalam penelitian berjumlah 226 siswa, sedangkan sampel dalam penelitian ini berjumlah 73 siswa. Pengambilan sampel ditentukan dengan teknik cluster random sampling. Pengumpulan data kompetensi pengetahuan IPS siswa dilakukan dengan metode tes dalam bentuk pilihan ganda. Data yang telah terkumpul selanjutnya dianalisis dengan statistik deskriptif dan statistik inferensial yaitu uji-t. Hasil analisis data dengan statistik deskriptif menunjukkan bahwa rata-rata gain skor kelompok eksperimen lebih tinggi dari pada ratarata gain skor kelompok kontrol $(0,368>0,160)$. Selanjutnya, hasil analisis data dengan uji-t menunjukkan thitung $=9,023>t_{\text {tabel }}=1,993$. Dengan demikian, dapat disimpulkan bahwa model pembelajaran Project Based Learning berlandaskan Tri Hita Karana berpengaruh terhadap kompetensi pengetahuan IPS. Hasil Penelitian ini diharapkan dapat menjadi salah satu refrensi dalam mengembangkan penelitian selanjutnya. Implikasi dari penelitian ini yaitu model ini bisa digunakan untuk menciptakan pembelajaran yang inovatif sehingga dapat memberikan kontribusi yang baik bagi pembelajaran.
\end{abstract}

Kata Kunci: PjBL; THK; Kompetensi Pengetahuan IPS

\begin{abstract}
Abstrac
The low competence of students' social science knowledge due to inactivity of students in the learning process and the lack of use of innovative models by teachers is the reason for this research. This study aims to determine the significant influence of project based learning models based on tri hita karana based on students' social science knowledge competence. This research is a quasi-experimental research with a research design using nonequivalent pretest-posttest control group design. The population in the study amounted to 226 students, while the sample in this study amounted to 73 students. Sampling was determined by cluster random sampling technique. The data collection of students' social science knowledge competencies is done by the test method in the form of multiple choice. The collected data is then analyzed with descriptive statistics and inferential statistics, namely the t-test. The results of data analysis with descriptive statistics show that the average gain score of the experimental group is higher than the average gain score of the control group (0.368>0.160). Furthermore, the results of data analysis with the t-test showed that $t_{\text {count }}=9.023>t_{\text {table }}=1.993$. So it can be concluded that the Project Based Learning model based on Tri Hita Karana affects the competence of social science knowledge. The results of this study are expected to be one of the references in developing further research. The implication of this research is that this model can be used to create innovative learning so that it can make a good contribution to learning.
\end{abstract}

Key Word: PjBL; THK; Social Science Knowledge

\section{PENDAHULUAN}

Kurikulum 2013 merupakan kurikulum berbasis tematik terintegratif. Menurut Setiadewi (2019) Kurikulum memberikan kontribusi untuk dapat mewujudkan sistem pendidikan yang berkualitas dan dapat menghasilkan sumber daya manusia yang unggul sehingga nantinya dapat bersaing tidak hanya di dalam negeri namun juga mampu bersaing di luar negeri. Handayani, (2017) menyatakan proses pembelajaran pada Kurikulum 2013 untuk semua jenjang dilaksanakan dengan menggunakan pendekatan saintifik. Pelaksanaan pembelajaran dengan menggunakan pendekatan saintifik bertujuan untuk mencapai kompetensi yang terdapat dalam pembelajaran. Wiyani (dalam Anjarsari, dkk, 2017) menyatakan bahwa pencapaian kompetensi adalah proses merancang pembelajaran mulai dari tujuan, materi, pengalaman belajar, sumber belajar, dan evaluasi berdasarkan karakteristik peserta didik agar peserta didik memiliki pengetahuan, sikap, dan keterampilan sebagai bekal hidupnya. Salah satu 
kompetensi yang dicapai yaitu kompetensi pengetahuan. Kompetensi pengetahuan mengukur sejauh mana siswa mampu menguasai muatan-muatan materi yang mereka pelajari, salah satunya yaitu muatan materi Ilmu Pengetahuan Sosial.

IPS merupakan salah satu cakupan materi yang membahas mengenai kondisi lingkungan sosial masyarakat. Wibawa, dkk (2018) mengungkapkan IPS merupakan salah satu kompetensi pengetahuan yang perlu ditingkatkan dalam diri siswa karena sangat dibutuhkan oleh siswa untuk nantinya dapat bergunan bagi siswa dalam bersosialisasi di masyarakat dan lingkungan sekitarnya. Menurut Susanto (dalam Puspitawangi, dkk., 2016) IPS adalah ilmu sosial dan humaniora serta kegiatan dasar manusia yang disajikan secara ilmiah untuk memberi wawasan dan pemahaman kepada peserta didik, khususnya di tingkat dasar. Cakupan mata pelajaran IPS terdiri dari Sejarah, Geografi, Ekonomi, serta ilmu sosial lainnya (Lasmawan 2016).

Tujuan dari IPS adalah untuk mengembangkan siswa agar peka terhadap masalah sosial yang terjadi di masyarakat, memiliki sikap mental positif terhadap perbaikan segala ketimpangan yang terjadi, dan terampil mengatasi setiap masalah yang terjadi sehari-hari baik yang menimpa dirinya sendiri maupun yang menimpa masyarakat (Rando \& Wali, 2018). Selain itu, menurut Mahdalena \& Sain (2020) tujuan IPS di sekolah dasar adalah membekali anak didik dengan pengetahuan sosial yang berguna dalam kehidupan kelak dimasyarakat. Berdasarkan tujuan tersebut, tentunya pelajaran IPS sangat penting dikuasai oleh peserta didik, karena dalam pelajaran IPS siswa diarahkan untuk memiliki mental yang positif dan mampu mengatasi permasalahan yang terjadi dalam kehidupan sehari-hari. Hal ini didukung oleh Aguswanto (2019) yang menyatakan bahwa pembelajaran IPS sangat penting bagi siswa dikarenakan IPS dirancang untuk membangun dan merefleksikan kemampuan peserta didik dalam kehidupan bermasyarakat yang selalu berubah dan berkembang secara terus menerus. Begitu pentingnya pembelajaran IPS maka pembelajaran IPS perlu dirancang agar dapat mengembangkan kemampuan peserta didik, baik pada aspek afektif, kognitif, ataupun psikomotorik. Menurut Antari, dkk (2017) pembelajaran IPS di sekolah seharusnya mampu membekali siswa dengan pengetahuan serta wawasan mengenai konsep dasar ilmu sosial dan humaniora, mempunyai kepekaan dan kesadaran tentang masalah sosial di lingkungannya dan dapat memecahkan masalah sosial dengan baik, sehingga siswa dapat terbina menjadi warga negara yang baik dan bertanggung jawab. Selain itu Segara (2016) menyatakan pembelajaran IPS pada pendidikan dasar secara ideal harus mampu membentuk peserta didik yang baik dan mampu berpikir secara cerdas, meningkatkan keterampilan sosial peserta didik, mampu menyeleksi dan mengaplikasikan nilai-nilai yang ada dalam agama, kebudayaan, bangsa dan Negara. Hal ini didukung dengan pendapat Budiyono (2018) yang menyatakan jika mengacu pada Permendiknas Tahun 2006, seharusnya pembelajaran IPS di Sekolah Dasar mampu mengkaji permasalahan-permasalahan serta peristiwa yang terjadidi kehidupan nyata.

Namun, dalam kenyataannya di sekolah keadaan pembelajaran IPS yang ideal sesuai dengan tujuan mata pelajaran IPS tidak tercapai. Pembelajaran IPS sangat menekankan jumlah pengetahuan yang harus dimiliki dan lebih menekankan pada hafalan daripada berpikir. Akibatnya mata pelajaran IPS menjadi mata pelajaran yang tidak menarik bagi siswa. Selain itu, guru yang memiliki pola konvensional dalam melakukan pembelajaran hanya mengandalkan satu metode juga menjadi salah satu pemicu mengapa mata pelajaran IPS dianggap membosankan bagi siswa (Kurniasari, 2020). Sejalan dengan pendapat Ginanjar (2016) yang menyatakan dalam implementasinya proses pembelajaran IPS selama ini lebih menekankan pada aspek kognitif, guru kurang mempersiapkan peserta didik untuk menjadi warga Negara sekaligus warga dunia yang baik, yang mempunyai keterampilan untuk hidup bermasyarakat, hidup berdampingan, bekerja sama, mengontrol diri, mengontrol emosi dan berbagi dengan sesama. Hal ini diperkuat oleh Larasati (2020) yang menyatakan bahwa penyebab rendahnya hasil belajar IPS dikarenakan guru masih menggunakan metode ceramah dan penugasan. Guru menggunakan media pembelajaran berupa gambar, sumber belajar juga hanya dari buku. Hal tersebut mengakibatkan siswa kurang memahami konsep-konsep yang diajarkan, karena kurang aktif dan tidak berinteraksi langsung.

Hal ini juga terjadi di Gugus Dr. Soetomo Kecamatan Denpasar Selatan Tahun Ajaran 2019/2020. Berdasarkan hasil observasi dan wawancara dengan wali kelas $\mathrm{V}$ diperoleh informasi bahwa kompetensi pengetahuan siswa pada muatan IPS masih sangat rendah, hal ini disebabkan oleh beberapa permasalahan yang dihadapi guru, yakni 1) Kurangnya keaktifan dan partisipasi siswa dalam mengikuti proses pembelajaran; 2) Kurang diterapkannya penggunaan model pembelajaran yang inovatif; 3) siswa cenderung jenuh dalam belajar. Berdasarkan wawancara yang dilakukan guru 
menyatakan bahwa guru lebih sering menggunakan metode ceramah dan penugasan untuk siswa karena merasa kesulitan dalam menggunakan model pembelajaran yang inovatif, guru mengalami kesulitan dalam menentukan model yang cocok digunakan dengan materi pelajaran IPS, dan juga kurangnya media pembelajaran dari sekolah sehingga menyebabkan guru hanya menggunakan media yang tersedia seperti papan tulis, dan buku sebagai media dan sumber materi. Sehingga hal ini berdampak terhadap rendahnya hasil belajar IPS siswa.

Jika dilihat dari pemaparan diatas, ini merupakan suatu masalah yang harus diatasi agar kompetensi pengetahuan siswa menjadi lebih baik. Untuk mengatasi permasalahan tersebut diperlukan suatu inovasi model pembelajaran yang dapat meningkatkan kompetensi pengetahuan IPS siswa. Salah satu model yang dapa digunakan yaitu model pembelajaran project-based learning. Model project-based learning merupakan salah satu model yang dapat menumbuhkan kratifitas dan keaktifan siswa. Menurut Wahyuni (2019) project based learning adalah model pembelajaran yang memberikan kesempatan kepada pendidik untuk mengelola pembelajaran di kelas dengan melibatkan kerja proyek. Kerja proyek memuat tugas-tugas yang kompleks berdasarkan permasalahan (problem) sebagai langkah awal dalam mengumpulkan dan mengintegrasikan pengetahuan baru berdasarkan pengalamannya dalam beraktivitas secara nyata dan menuntun peserta didik untuk melakukan kegiatan merancang, memecahkan masalah, membuat keputusan, melakukan kegiatan investigasi, serta memberikan kesempatan peserta didik untuk bekerja secara mandiri maupun kelompok. Hasil akhir dari kerja proyek tersebut adalah suatu produk yang antara lain berupa laporan tertulis atau lisan, presentasi atau rekomendasi.

Senada dengan itu menurut Hosnan (dalam Nurjanah \& Esa, 2019) menyatakan bahwa pembelajaran berbasis proyek merupakan strategi pembelajaran yang menggunakan proyek/kegiatan sebagai sarana pembelajaran untuk mencapai kompetensi sikap, pengetahuan, dan keterampilan. Pendapat lainnya juga dikemukakan oleh Mayuni, dkk (2019) yang mengungkapkan model project based learning (PjBL) merupakan model, strategi, atau metode pembelajaran yang berpusat pada siswa. Dimana siswa diajak untuk mengembangkan sendiri kemampuan yang ada dalam diri mereka dengan menciptakan proyek belajar (kegiatan), sehingga diharapkan dapat mengembangkan kemampuan kretifitas dan berfikir kritis mereka akan terbangun dengan menggunakan model ini dimana untuk menyelesaikan sebuah proyek perlulah usaha dan kerja keras serta bekerja secara kooperatif dengan kelompok. Berdasarkan pemaparan tersebut dapat disimpulkan bahwa model project based learning merupakan pembelajaran yang dalam penerapannya melibatkan siswa untuk aktif dan ikut serta dalam pengerjaan sebuah proyek yang nantinya akan menghasilkan sebuah karya yang nantinya akan dipersentasikan.

Model pembelajaran Project Based Learning mewajibkan siswa untuk belajar dan menghasilkan sebuah karya, oleh karena itu model ini dapat meningkatkan motivasi siswa untuk belajar, meningkatkan kecakapan siswa dalam pemecahan masalah dan meningkatkan kerjasama siswa dalam kerja kelompok (Saputro \& Rayahu, 2020). Adapun menurut Devi, (2019) Langkah-langkah model Project Based Learning meliputi: (1) pertanyaan mendasar yaitu pemberian rangsangan pembelajaran berupa pertanyaan kepada siswa sehingga siswa timbul rasa ingin tahu untuk melakukan penyelidikan; (2) mendesain perencanaan proyek yaitu pemberian kesempatan kepada siswa untuk mengidentifikasi masalah dan dirumaskan dalam bentuk hipotesis dan rencana kerja berproyek; (3) menyusun jadwal yaitu menentukan waktu kerja proyek; (4) memonitor siswa yaitu tindakan pemantauan untuk mengurangi risiko kesalahan berproyek; (5)menguji hasil yaitu pembuktian benar atau tidaknya hipotesis yang ditetapkan; (6) menarik kesimpulan (generalization) yaitu proses penarikan kesimpulan dari hal yang dilakukan.

Karakteristik dari pembelajaran Project-Based Learning (PjBL) yaitu mengembangkan kemampuan berfikir siswa yang memungkinkan mereka untuk memiliki kreativitas, terampil, dan mendorong mereka untuk bekerja sama (Indriyani \& Wrahatno, 2019). Adapun kelebihan dari model Project Based Learning yaitu : 1) memberikan kesempatan belajar bagi siswa untuk berkembang sesuai kondisi dunia nyata; 2) melibatkan siswa untuk belajar mengumpulkan informasi dan menerapkan pengetahuan tersebut untuk menyelesaikan permasalahan di dunia nyata; dan 3) membuat suasana menjadi menyenangkan. Sedangkan kelemahan model pembelajaran Project Based Learning yaitu 1) membutuhkan guru yang terampil dan mau belajar; 2) membutuhkan fasilitas, peralatan, dan bahan yang memadai; 3) kesulitan melibatkan semua siswa dalam kerja kelompok (Sunita dkk, 2019). 
Hal ini didukung dengan penelitian sebelumnya yang telah dilakukan oleh Himmah (2017) yang menyatakan bahwa bahwa model pembelajaran Project Based Learning berpengaruh terhadap hasil belajar siswa kelas IV SDN Punggul 1 Gedangan Sidoarjo. Hal ini dibuktikan dengan hasil perhitungan uji hipotesis menggunakan rumus Independent Sample T-Test. Hasil uji pengaruh tersebut diperoleh setelah adanya perlakuan dikelas eksperimen. Dari perhitungan uji hipotesis diperoleh hasil $t_{\text {hitung }}<$ $t_{\text {tabel, }}$ dengan signifikansi lebih besar dari signifikansi yang ditetapkan, maka Ho ditolak dan Ha diterima. Hal tersebut berarti terdapat pengaruh yang signifikan terhadap nilai posttest siswa kelas IV B SDN Punggul 1. Penelitian lainnya juga dilakukan oleh Surya (2018) yang menyatakan bahwa penggunaan model pembelajaran Project Based Learning (PjBL) dapat meningkatkan hasil belajar dan kreatifitas siswa kelas III SD Negeri Sidorejo Lor 01 Salatiga, Semester II Tahun pelajaran 2018/2019. Hal ini terlihat pada peningkatan hasil belajar siswa yakni pada pra siklus ketuntasan belajar siswa sebesar $46 \%$ lalu meningkat sebesar $72 \%$ pada Siklus I dan meningkat lagi pada Siklus II sebesar 92\% ketuntasan belajar siswa. Selanjutnya penelitian yang dilakukan oleh Niswara (2019) yang menyatakan bahwa ada pengaruh penerapan model Project Based Learning berbantu media Puzzle terhadap High Order Thinking Skill kriteria berpikir kritis siswa. Dibuktikan pada hasil analisis uji normalitas dan uji hipotesis (uji-t) yang menunjukkan bahwa berdistribusi normal, kemudian data hipotesis diterima.

Penelitian ini memiliki perbedaan dengan penelitian dengan model pembelajaran Project Based Learning lainnya. Hal ini disebabkan penelitian ini di kolaborasikan dengan salah satu kearifan lokal yang ada di Bali yaitu Tri Hita Karana. Menurut Wiana (dalam Tiarini, 2019) menyatakan "Tri Hita Karana berasal dari bahasa sansekerta, istilah Tri Hita Karana berasal dari kata Tri yang artinya tiga (3), Hita artinya bahagia dan Karana Penyebab. Dengan demikian Tri Hita Karana merupakan tiga penyebab kebahagiaan". Nama Tri Hita Karana inilah yang dijadikan judul untuk menyebutkan ajaran yang mengajarkan agar manusia mengupayakan hubungan harmonis dengan Tuhan, dengan sesama manusia dan dengan alam lingkungannya. Wiana (dalam Santhi, 2018) menyatakan bahwa "mencapai kehidupan yang bahagia dengan melakukan hubungan harmonis dengan Tuhan (Parhyangan), dengan sesama manusia (Pawongan) dan dengan alam lingkungan sekitar (Palemahan) ini merupakan bagian Tri Hita Karana". Berdasarkan uraian yang telah di paparkan dapat disimpulkan bahwa konsep Tri Hita Karana adalah memiliki hubungan yang baik dengan Tuhan (Parhyangan), hubungan yang baik dengan sesama manusia (Pawongan), dan hubungan yang baik dengan lingkungan (Palemahan), hal tersebut harus dilakukan demi keharmonisan dan ketentraman antar sesama mahluk hidup. Ketiga penerapan Tri Hita Karana dalam pembelajaran di Sekolah Dasar dijelaskan sebagai berikut: (1)Hubungan baik manusia dengan Tuhan Yang Maha Esa yaitu dengan cara sembahyang, melaksanakan yadnya, dan mengamalkan ajaran agama, (2) Hubungan baik manusia dengan sesama manusia yati dengan cara mengasihi serta saling membimbing, (3) Hubungan baik manusia dengan lingkungannya yaitu dengan cara tidak boleh melakukan pemburuan hewan dan penebagan pohon sembarangan, tidak boleh membuang sampah sembarangan, karena jika hal tersebut dilakukan dapat mengganggu keseimbangan alam. Sehingga dengan diterapkannya nilai kearifan lokal Tri Hita Karana dalam pembelajaran, guru bisa menanamkan nilai kearifan lokal yang bermanfaat bagi siswa dengan mengamalkan Tri Hita Karana dalam kehidupan sehari-hari yang dapat membawa dampak positif bagi siswa.

Model pembelajaran Project Based Learning Berlandaskan Tri Hita Karana merupakan perpaduan antara model pembelajaran yang memberikan kesempatan kepada setiap siswa untuk memberikan kontribusi mereka serta mendengarkan pandangan dan pemikiran anggota yang lain dan dibarengi dengan pengamalan nilai-nilai kearifan lokal tri hita karana. Adapun Model pembelajaran Project Based Learning Berlandaskan Tri Hita Karana terdiri dari 6 tahapan yaitu 1) Penentuan Proyek, Guru meminta siswa untuk menentukan jenis kegiatan atau karya yang akan mereka kerjakan, sesuai dengan kebutuhan masing-masing. Dilaksanakan dengan berlandaskan Tri Hita Karana, dengan konsep Parahyangan; 2) Penyusunan Proyek, tahap ini siswa mempersiapkan segala keperluan yang akan digunakan. Dilaksanakan berlandaskan Tri Hita Karana, dengan konsep Pawongan; 3) Pembuatan Jadwal, Secara Bersama-sama siswa dan guru membuat jadwal dalam penyelesaian kegiatan secara bertahap. Dilaksanakan berlandaskan Tri Hita Karana, dengan konsep Pawongan; 4) Penyelesaian Proyek, Guru memotivasi, mengarahkan, dan mengkordinasikan agar proyek yang dibuat selesai tepat waktu. Dilaksanakan berlandaskan Tri Hita Karana, dengan konsep Parahyangan dan pawongan; 5) Penyampaian hasil kegiatan, pada tahap ini siswa didorong untuk berani mempertanggungjawabkan atas kegiatan-kegiatan yang telah dijalaniny, dapat berupa menampilkan 
di pameran, pegelaran, maupun diskusi kelas. Dilaksanakan berlandaskan Tri Hita Karana, dengan konsep Palemahan; 6) Evaluasi proses dan hasil kegiatan, melakukan evaluasi dari pelaksanaan yang telah dilakukan dan penyampaian pengalaman dan permasalahan selama berkegiatan. Dilaksanakan berlandaskan Tri Hita Karana, dengan konsep Parahyangan. Penerapan Model pembelajaran Project Based Learning Berlandaskan Tri Hita Karana tentunya dapat membuat siswa lebih aktif dalam proses pembelajaran dengan mengaitkan nilai Tri Hita Kara dalam kehidupan sehari-hari. Hal ini didukung dengan penelitian yang dilakukan Indrayani (2019) yang menyatakan bahwa skor rata - rata hasil belajar kelompok eksperimen yang dibelajarkan menggunakan model pembelajaran siklus belajar berbasis tri hita karana lebih tinggi dibandingkan dengan skor rata - rata hasil belajar kelompok kontrol. Sehingga model pembelajaran siklus belajar berbasis tri hita karana berpengaruh terhadap hasil belajar siswa.

" Penelitian ini bertujuan untuk mengetahui pengaruh yang signifikan model pembelajaran project based learning berlandaskan Tri Hita Karana terhadap kompetensi pengetahuan IPS siswa kelas V SD N Gugus Dr. Soetomo Kecamatan Denpasar Selatan Tahun ajaran 2019/2020”..

\section{METODE}

Penelitian ini dilaksanakan di kelas V SDN Gugus Dr. Soetomo Kecamatan Denpasar Selatan Tahun Ajaran 2019/2020. Penelitian ini merupakan jenis penelitian eksperimen semu (quasi eksperiment) dengan menggunakan pretest-posttest non equivalent control group design. Populasi dari penelitian ini yakni kelas V Gugus Jendral Sudirman Kecamatan Denpasar Selatan tahun ajaran 2019/2020 yang terdiri dari 6 kelas dalam 4 sekolah. Jumlah keseluruhan populasi dalam penelitian adalah 226 siswa. Penentuan sampel penelitian ditentukan dengan menggunakan teknik cluster random sampling. Cara yang digunakan untuk menentukan sampel yaitu dengan cara pengundian kelas yang muncul dalam undian tersebut diberi pre test yanng bertujuan untuk menyetarakan kedua kelompok. Adapun perolehan uji kesetaraan uji $t$ di peroleh $t_{\text {hitung }}<t_{\text {tabel }}(1,870<1,993)$, sehingga $H_{0}$ diterima dan kelompok dinyatakan setara. Berdasarkan pengundian tersebut diperoleh sampel dalam penelitian ini adalah kelas V B SDN 9 Sesetan dengan jumlah 36 siswa sebagai kelompok eksperimen dan kelas V SDN 14 Sesetan dengan jumlah 37 siswa sebagai kelompok kontrol.

Data yang dikumpulkan dalam penelitian ini adalah kompetensi pengetahuan IPS siswa. Metode yang digunakan untuk mengumpulkan data adalah metode tes. Jenis tes yang digunakan yaitu tes objektif pilihan ganda dengan penskoran benar mendapatkan skor 1 dan salah mendapatkan skor 0 . Tes hasil belajar yang dikembangkan disesuaikan dengan kompetensi dasar yang harus dicapai siswa. Kompetensi dasar yang diukur dalam penelitian ini yakni Mengidentifikasi faktor-faktor penting penyebab penjajahan bangsa Indonesia dan upaya bangsa Indonesia dalam mempertahankan kedaulatannya. Adapun kisi-kisi yang digunakan pada penelitian telah disesuaikan dengan kompetensi dasar muatan IPS yang harus dicapai siswa dan juga disesuaikan dengan ranah kognitif taksonomi Bloom yang terdiri dari C3, C4, dan C5. Kisi-kisi dalam penelitian ini dikembangkan menjadi 11 indikator dengan rincian 3 indikator untuk tingkat kognitif C3, 6 indikator untuk tingkat kognitif C4, dan 2 indikator untuk tingkat kognitif C5. Untuk memastikan kualitas instrumen yang dibuat, maka dilakukan pengujian instrumen oleh pakar yang membidangi dan dilanjutkan dengan diujicobakan ke siswa lainnya. Setelah dilakukan pengujian instrumen maka dilanjutkan dengan uji validitas isi, validitas butir tes, reliabilitas, uji daya beda, dan uji tingkat kesukaran untuk memilah soal yang layak untuk digunakan. Dari hasil uji instrumen tersebut didapatkan bahwa 10 soal tidak layak untuk digunakan dan 30 soal layak untuk digunakan.

Metode analisis data yang digunakan pada penelitian ini yakni menggunakan metode analisis statistik deskriptif dan metode analisis statistik inferensial. Analisis statistik deskriptif berfungsi untuk memaparkan serta menyajikan data. Sedangkan analisis statistik inferensial berfungsi untuk menggeneralisasi hasil penelitian yang telah dilaksanakan. Adapun analisis statistik deskriptif yang digunakan pada penelitian ini yaitu mencari mean, standar deviasi, varians, serta menentukan penilaian skala lima. Sedangkan, analisis statistik inferensial digunakan untuk menguji hipotesis menggunakan uji-t (polled varians). Namun, sebelum dihitung menggunakan uji-t terlebih dahulu dilakukan uji prasyarat analisis data yaitu uji normalitas sebaran (Kolmogorov-smirnov) data dan uji homogenitas sebaran data(Uji F). Untuk perhitungan uji asumsi dan uji hipotesis dilakukan secara manual menggunakan rumus yang sesuai. 


\section{HASIL DAN PEMBAHASAN}

Penelitian ini adalah penelitian eksperimen dengan memberikan perlakuan pada dua sampel yaitu kelas V SD Negeri 9 Sesetan menjadi kelas eksperimen dan kelas V SD Negeri 14 Sesetan menjadi kelas kontrol. Pada kelas eksperimen diberikan perlakuan model pembelajaran Project Based Learning berlandaskan Tri Hita Karana sedangkan pada kelas kontrol diberikan perlakuan model pembelajaran konvensional. Setiap kelas diberikan perlakuan sebanyak 6 kali dan setelahnya diberikan post-test yang bertujuan untuk mendapatkan data nilai dari setiap sampelnya.

Berdasarkan analisis deskriptif data skor rata-rata kompetensi pengetahuan IPS dari hasil posttest pada kelas eksperimen adalah 0,364 dengan perolehan nilai tertinggi 0,583 , dan nilai terendah 0,142 , nilai varians sebesar 0,011 dan standar deviasi sebesar 0,103 . Sedangkan nilai rata-rata hasil belajar IPS dari hasil posttest pada kelas kontrol adalah 0,160 dengan perolehan nilai tertinggi 0,545, dan nilai terendah 0,555, nilai varians sebesar 0,008 dan standar deviasi sebesar 0,093. Data skor kompetensi pengetahuan IPS siswa menunjukkan bahwa kelompok siswa yang dibelajarkan melalui model Project Based Learning berlandaskan Tri Hita Karana memiliki rata-rata yang lebih tinggi dari kelompok siswa yang dibelajarkan melalui pembelajaran konvensional. Sebelum dilakukan uji hipotesis, terlebih dahulu dilakukan uji normalitas sebaran data dan uji homogenitas varians.

Sebelum melakukan pengujian hipotesis data yang diperoleh terlebih dahulu dilakukan uji prasyarat yang terdiri dari uji Normalitas dan Uji homogenitas. Uji normalitas dilaksanakan guna mengetahui sebaran data dari skor kompetensi pengetahuan IPS siswa kelompok eksperimen maupun kontrol berdistribusi normal atau tidak. Uji normalitas sebaran data pada penelitian ini menggunakan uji Kolmogorov-Smirnov, dengan menggunakan taraf signifikansi 5\%. Hasil pengujian normalitas data kompetensi pengetahuan IPS siswa kelas eksperimen dan kontrol yaitu sebaran data kelompok eksperimen memperoleh harga nilai maksimum $\left|\mathrm{F}_{\mathrm{T}}-\mathrm{F}_{\mathrm{S}}\right|=0,098<$ harga nilai tabel kolmogorovsmirnov $=0,199$ maka sebaran data dari data gain skor ternormalisasi kompetensi pengetahuan IPS kelompok eksperimen berdistribusi normal. Sedangkan pada kelompok kontrol harga nilai maksimum $\left|\mathrm{F}_{\mathrm{T}}-\mathrm{F}_{\mathrm{S}}\right|=0,191<$ harga nilai tabel kolmogorov-smirnov $=0,196$, maka sebaran data dari data gain skor ternormalisasi kompetensi pengetahuan IPS kelompok kontrol dinyatakan berdistribusi normal.

Uji homogenitas varians antar kelompok bertujuan untuk memeriksa kesamaan varians antar kelompok perlakuan. Dalam penelitian ini, uji homogenitas dilakukan terhadap data perolehan dari kedua kelompok. Tujuan dari dilakukannya uji homogenitas varians adalah untuk mengetahui varians homogen atau tidak. Pada uji homogenitas varians dipergunakan rumus yaitu dengan menggunakan uji $\mathrm{F}$ (fisher). Hasil pengujian homogenitas data kompetensi pengetahuan IPS siswa antara kelas eksperimen dan kontrol diperoleh hasil $F_{\text {hitung }}<F_{\text {tabel }}(1,211<1,800)$. Hal ini menunjukkan data hasil belajar IPS kelas eksperimen dan kelas kontrol memiliki varian yang homogen. Setelah dilaksanakannya uji normalitas sebaran data maupun uji homogenitas varians diperoleh data yang berasal dari kedua kelompok dinyatakan berdistribusi normal dan mempunyai varians yang homogen. Berdasarkan hal tersebut, dilanjutkan pada pengujian hipotesis penelitian. Uji hipotesis dilakukan dengan menggunakan analisis uji-t (rumus polled varians), dengan kriteria pengujian dari uji-t yaitu jika $t_{\text {hitung }}>t_{\text {tabel }}$ dengan $\mathrm{dk}=\mathrm{n} 1+\mathrm{n} 2-2$ pada taraf signifikansi $5 \%(\alpha=0,05)$ dinyatakan $\mathrm{H}_{\mathrm{o}}$ diterima dan $\mathrm{H}_{1}$ ditolak. Sedangkan jika $\mathrm{t}_{\text {hitung }}>\mathrm{t}_{\text {tabel, }}$, dinyatakan $\mathrm{H}_{\mathrm{o}}$ ditolak da $\mathrm{H}_{1}$ diterima. Adapun hasil uji hipotesis disajikan pada tabel 1berikut.

Tabel 1. Uji Hipotesis

\begin{tabular}{ccccccccc}
\hline No & Sampel & $\mathrm{N}$ & $\mathrm{Dk}$ & $\overline{\mathrm{X}}$ & $\mathrm{S}^{2}$ & $\mathrm{t}_{\text {hitung }}$ & $\mathrm{t}_{\text {tabel }}$ & Simpulan \\
\hline 1 & Kelas Eksperimen & 36 & \multirow{2}{*}{71} & 0,368 & 0,011 & \multirow{2}{*}{9,023} & \multirow{2}{*}{1,993} & \multirow{2}{*}{$\mathrm{H}_{\mathrm{o}}$ ditolak } \\
2 & Kelas Kontrol & 37 & & 0,160 & 0,009 & & & \\
\hline
\end{tabular}

Pada tabel 1, diperoleh bahwa nilai $t_{\text {hitung }}=9,023$ dan $t_{\text {tabel }}=1,993$ untuk $\mathrm{dk}=71$ pada taraf signifikansi $5 \%$ sehingga nilai $t_{\text {hitung }}>t_{\text {tabel }}(9,023>1,993)$, maka $\mathrm{H}_{0}$ ditolak dan $\mathrm{H}_{1}$ diterima. Hal ini menunjukkan bahwa terdapat pengaruh yang signifikan kompetensi pengetahuan IPS antara kelas yang diterapkan model pembelajaran Project Based Learning berlandaskan Tri Hita Karana dengan kelas yang dibelajarkan secara konvensional pada siswa kelas V SD Negeri Gugus Dr. Soetomo Tahun Ajaran 2019/2020.

Perbedaan kompetensi pengetahuan IPS antara kelompok eksperimen yang dibelajarkan dengan model Project Based Learning berlandaskan Tri Hita Karana dan kelompok kontrol yang dibelajarkan dengan model konvensional disebabkan karena perlakuan yang diberikan baik pada 
langkah-langkah pembelajaran maupun proses pembelajaran yang berbeda. Penggunaan model pembelajaran Project Based Learning berlandaskan Tri Hita Karana membuat pembelajaran yang dilakukan menjadi sangat efektif karena melibatkan siswa untuk berkarya dan mengembangkan pengetahuannya sendiri dengan didampingi oleh guru sesuai model pembelajaran yang diberikan. Hal ini terlihat dari keantusiasan siswa dalam mengerjakan permasalahan yang diberikan guru, baik dari mendesain perencanaan pryoek sampai pengujian dugaan jawaban dari permasalahan yang diberika. Hal ini didukung oleh pendapat Fitri, dkk (2018) yang menyatakan bahwa model PjBL mengharuskan siswa aktif dalam memecahkan permasalahan dengan menggagas sebuah ide yang dapat digeneralisasikan menjadi sebuah produk sebagai hasil dari kegiatan proyek. Dalam hal ini siswa dapat melatih kemampuan berpikir tingkat tinggi yang mereka miliki. Hasil penelitian ini sejalan dengan hasil penelitian Sucipto (2017) bahwa dengan model project based learning siswa dapat berpatisipasi penuh saat pembelajaran, karena model ini dituntut agar dapat mengkonstruk pengetahuan mereka. Setiap anggota kelompok memiliki tanggungjawab masing-masing dalam mengerjakan tugas proyek, sehingga tidak ada yang dianggap menumpang kepada anggota yang lain.

Model pembelajaran Project Based Learning berlandaskan Tri Hita Karana menciptakan suasana belajar baru di dalam kelas hal ini dapat dilihat pada awalnya siswa yang unggul di kelas saja yang berani menjawab soal yang diberikan oleh guru sedangkan siswa lain yang mampu untuk menjawab soal yang diberikan oleh guru tidak berani untuk menjawab karena enggan. Namun pada saat proses pembelajaran dengan menggunakan model pembelajaran Project Based Learning berlandaskan Tri Hita Karana siswa lebih semangat belajar, antusias untuk belajar lebih tinggi. Hal ini dapat dilihat dari siswa yang sudah mulai berani untuk mengungkapkan pendapat mereka dan bertanya jika mengalami kesulitan pada saat diskusi. Hal ini didukung dengan pendapat Rahayu \& Hartono (2016) yanag menyatakan bahwa model pembelajaran Project Based Learning ialah model pembelajaran yang memberdaya-kan siswa untuk mencapai konten pengetahuan mereka sendiri melalui kegiatan penugasan kompleks dan pada akhirnya siswa menghasil-kan produk karya siswa bernilai dan realistik. Hal ini didukung dengan hasil penelitian yang dilakukan oleh Wijanarko, dkk (2017) yang menyatakan bahwa model Project Based Learning terbimbing efektif memberdayakan keterampilan proses sains siswa karena pada kegiatan pembelajaran dengan model Project Based Learning membuat siswa lebih percaya diri dalam mendemonstrasikan proyek yang dibuat.

Selain itu, pembelajaran dengan model Project Based Learning berlandaskan Tri Hita Karana juga melatih siswa dalam bekerjasama (kolaborasi), model ini melatih siswa untuk menerima pendapat orang lain, dan juga bekerjasama dalam menyelesaikan projek yang dibuat agar tepat waktu. Hal ini terlihat pada saat siswa mulai mengerjakan projek yang mereka dapatkan mereka saling membantu dan mau mengerjakan tugasnya masing-masing tanpa ada perdebatan antara anggota kelompok. Hal ini sesuai dengan pendapat Kurniawan, dkk (2018) yang menyatakan bahwa model pembelajaran PjBL merupakan model yang memberikan kesempatam kepada siswa untuk menyampaikan ide atau pendapat, mendengarkan pendapat orang lain, dan merefleksikan idenya kepada orang lain. Hal ini sejalan penelitian yang dilakukan oleh Pratiwi, dkk (2018) yang menyatakan bahwa model project based learning berbantuan metode edutaiment dapat meningkatkan kemampuan kerjasama dan hasil belajar IPS siswa. Model Project Based Learning berlandaskan Tri Hita Karana memberikan pembelajaran bermakna kepada siswa sehingga pembelajaran mudah dipahami siswa. Hal ini juga dilatarbelakangi oleh kelebihan model Project Based Learning menurut Sunita (2019) yaitu 1) memberikan kesempatan belajar bagi siswa untuk berkembang sesuai kondisi dunia nyata, 2) melibatkan siswa untuk belajar mengumpulkan informasi dan menerapkan pengetahuan tersebut untuk menyelesaikan permasalahan di dunia nyata, dan 3) membuat suasana menjadimenyenangkan.

Pembelajaran dengan model project based learning berdasarkan Tri Hita Karana juga mengajarkan siswa tentang upaya menjaga hubungan harmonis dengan Tuhan, sesama manusia, dan dengan alam lingkungannya dengan mengaitkan konsep Tri Hita Karana dengan materi yang diajarkan kepada siswa. Adapun bagian dari Tri Hita Karana yaitu Parhyangan, Pawongan, dan Palemahan. Parhyangan merupakan hubungan manusia dengan Tuhan. Dalam hal ini siswa diajarkan agar memiliki rasa syukur kepada Tuhan yang telah memberikan kesempatan untuk bisa melaksanakan pembelajaran dan berdoa agar pembelajaran berjalan dengan lancar. Misalnya, pada saat siswa sebelum memulai pembelajaran atau mengerjakan projek yang mereka dapatkan guru mengajak siswa untuk berdoa terlebih dahulu. Kedua, Pawongan yaitu hubungan yang harmonis antar sesama manusia. Pada bagian ini siswa diajarkan untuk menjalin interaksi dengan sesama siswa, guru, dan seluruh warga sekolah. Misalnya, pada saat pembagian kelompok siswa tidak memilih-milih teman, 
atau pada saat tahap pengerjaan projek siswa tidak berdebat dengan anggota kelompok atau kelompok yang lain karena adanya perbedaan pendapat. Ketiga, Palemahan yaitu hubungan yang harmonis antara manusia dengan lingkungan sekitarnya. Bagian ini siswa diajarkan untuk memiliki rasa peduli dengan lingkungan sekitarnya, terutama lingkungan sekolah tempat belajar. Misalnya sebelum proses pembelajaran dimulai atau berakhir guru mengajak siswa untuk memperhatikan kebersihan lingkungan sekitarnya. Berdasarkan pernyataan tersebut, maka tepatlah model pembelajaran project based learning didasarkan dengan Tri Hita Karana.

Berbeda halnya dengan pembelajaran dengan model konvensional yang lebih banyak menggunakan metode ceramah dan komunikasi yang hanya bersifat satu arah. Sehingga siswa menjadi kurang diberikan kesempatan untuk berinteraksi dengan temannya. Hal ini sesuai dengan karakteristik pembelajaran konvensional menurut Agung(2014:159) yaitu, 1) Peserta didik merupakan penerima informasi pasif, yang dimkasud adalah peserta didik menerima pengetahuan dari pendidik sebagai bagian informasi dan keterampilan yang dimiliki sesuai standar, 2). belajar secara individual, 3) pembelajaran bersifat abstrak dan teoritis, 4) perilaku dibangun atas kebiasaan, 5) pengetahuan bersifat final, 6) pendidik adalah penemu jalannya proses pembelajaran, 7) perilaku baik berdasarkan motivasi ekstrisik, 8) pembelajaran berpusat pada pendidik (teacher oriented) dan 9) pembelajaran bersifat mekanistik. Hal ini sejalan dengan temuan Herlina (2019) yang menyatakan pembelajaran dengan model konvesional siswa hanya mengandalkan penjelasan dari guru dan hanya dituntut pada daya ingat atau hafalan. Sehingga hal tersebut membuat siswa menjadi kurang aktif dalam menguasi materi yang diajarkan.

Berdasarkan temuan dalam penelitian ini, dapat dinyatakan bahwa kelompok siswa yang dibelajarkan dengan model pembelajaran project based learning didasarkan dengan Tri Hita Karana lebih berpengaruh positif terhadap sikap toleransi siswa dibandingkan dengan kelompok siswa yang dibelajarkan dengan model konvensional. Hal ini dapat dilihat keaktifan siswa di kelompok siswa yang dibelajarkan dengan model pembelajaran project based learning didasarkan dengan Tri Hita Karana lebih tinggi jika dibandingkan dengan kelompok siswa yang dibelajarkan dengan model konvensional. Sehingga model pembelajaran project based learning didasarkan dengan Tri Hita Karana berpengaruh positif terhadap kompetensi pengetahuan IPS siswa.

Keberhasilan model pembelajaran project based learning didasarkan dengan Tri Hita Karana didukung oleh hasil penelitian yang dilakukan Dewi (2017) dengan hasil penelitian menunjukkan terdapat perbedaan yang signifikan menunjukkan bahwa model Project Based Learning berbasis Outdoor Study berpengaruh terhadap hasil belajar IPA siswa dibandingkan dengan menggunakan pembelajaran konvensional. Selain itu, hasil penelitian ini juga diperkuat dengan hasil penelitian yang dilakukan oleh Tiarini (2019) yang menunjukkan bahwa terdapat perbedaan hasil belajar IPA antara siswa yang mengikuti model pembelajaran Problem Based Learning Berorientasi Tri Hita Karana dan siswa yang mengikuti model pembelajaran Konvensional pada siswa kelas V SD Gugus IV Kecamatan Banjar.

Berdasarkan pembahasan di atas maka model pembelajaran Model Project Based Learning berlandaskan Tri Hita Karana berpengaruh dalam peningkatan kompetensi pengetahuan IPS siswa kelas V SD N Gugus Dr. Soetomo Kecamatan Denpasar Selatan Tahun ajaran 2019/2020. Berdasarkan hasil penelitian dan pembahasan yang telah dijelaskan, implikasi dari penelitian ini terdiri dari implikas teoretis dan implikasi praktis. Adapun implikasi teoretis dalam penelitian ini yaitu Kompetensi pengetahuan IPS siswa dipengaruhi pemilihan model yang tepat. Sedangkan implikasi praktis dalam penelitian ini yaitu Model Project Based Learning berlandaskan Tri Hita Karana dapat dijadikan refrensi bagi guru untuk meningkatkan kompetensi pengetahuan IPS siswa menjadi lebih baik.

\section{SIMPULAN DAN SARAN}

Hasil penelitian ini menunjukkan bahwa terdapat pengaruh yang sifgnifikan model pembelajaran project based learning berlandaskan tri hita karana terhadap kompetensi pengetahuan IPS siswa. Hal ini dapat dilihat dari skor rata-rata yang diperoleh oleh kelas yang menerapkan model pembelajaran project based learning berlandaskan tri hita karana lebih tinggi dibandingkan dengan kelas yang menerapkan model konvesional. Dengan demikian, model pembelajaran project based learning berlandaskan tri hita karana berpengaruh terhadap kompetensi pengetahuan IPS siswa. Adapun saran kepada phak-pihak terkait yaitu (1) Kepada guru, disarankan agar lebih inovatif dan kreatif dalam memberikan sumber pelajaran dan menggunakan model Project Based Learning berlandaskan Tri Hita 
Karana khususnya dalam kompetensi IPS maupun kompetensi lainnya yang mampu mendorong siswa untuk kreatif dan mengembangkan hasil belajarnya (2) Kepada kepala sekolah, disarankan agar dapat menggunakan hasil penelitian ini sebagai pendukung sumber belajar guru dalam meningkatkan kualitas pembelajaran dengan menciptakan pembelajaran yang menarik di sekolah sehingga sekolah mampu menghasilkan siswa yang berkualitas. (3) Kepada peneliti lain, disarankan agar hasil penelitian ini digunakan sebagai referensi untuk melaksanakan penelitian selanjutnya atau menemukan inovasi kegiatan pembelajaran lainnya yang bermakna bagi siswa.

\section{DAFTAR PUSTAKA}

Agung, A. A. G. (2014). Metodologi Penelitian Pendidikan. Aditya Media Publishing.

Aguswanto. (2019). Makalah Pembelajaran IPS SD/MI. Murobbi: Jurnal Ilmu Pendidikan Dan Kependidikan, 1(1). http://murobbi.com/index.php/robbi/article/view/8

Anjarsari, K. Y., Suniasih, N. W., \& Sujana, I. W. (2017). Pengaruh Model Pembelajaran Talking Chips Berbasis Tri Hita Karana Terhadap Kompetensi Pengetahuan IPS. Mimbar PGSD, 5(2), 1-11.

Antari, N. L. P. Y., Wiarta, I. W., \& Putra, M. (2017). Pengaruh Model Pembelajaran Kooperatif Tipe Two Stay Two Stray (Tsts) Berbantuan Multimedia Terhadap Kompetensi Pengetahuan Ips Siswa Kelas V Sd Gugus Letda Made Putra. Mimbar PGSD, 5(2), 1-10.

Devi, S. K., Ismanto, B., \& Kristin, F. (2019). Peningkatan kemandirian dan hasil belajar tematikmelalui project based learning. Jurnal Riset Teknologi Dan Inovasi Pendidikan, 2(1), 55-65.

Dewi, N. P. C., Negara, I. G. A. O., \& Suadnyana, I. N. (2017). Pengaruh Model Project Based Learning Berbasis Outdoor Study Terhadap Hasil Belajar IPA Siswa Kelas V. Mimbar PGSD, 5(2), 1-10.

Fitri, H., Dasna, I. W., \& Suharjo. (2018). Pengaruh Model Project Based Learning (PjBL) Terhadap Kemampuan Berpikir Tingkat Tinggi Ditinjau dari Motivasi Berprestasi Siswa Kelas IV Sekolah Dasar. BRILIANT: Jurnal Riset Dan Konseptual, 3(2), 201-212.

Ginanjar, A. (2016). Penguatan Peran IPS Dalam Meningkatkan Keterampilan Sosial Peserta Didik. Harmony, 1(1), 118-126.

Handayani, N. M. D., Ganing, N. N., \& Suniasih, N. W. (2017). Model Pembelajaran Picture And Picture Berbantuan Media Audio-Visual Terhadap Kompetensi Pengetahuan IPA. Journal of Education Technology, 1(3), 176-182.

Herlina, M., Rahayu, I. Y., \& Wiksya, D. (2019). Pengaruh Model Pembelajaran Group Investigation (Gi) Terhadap Berpikir Kritis Dan Keterampilan Sosial Siswa Dalam Pembelajaran IPA Biologi Kelas X SMAN 2 Argamakmur. Jurnal Pendidikan Dan Pembelajaran Biologi, 3(2), 142-152.

Himmah, F. (2017). Pengaruh Model Project Based Learning terhadap Hasil Beljar Siswa Kelas IV Sdn Punggul 1 Gedangan Sidoarjo. Jurnal Penelitian Pendidikan Guru Sekolah Dasar, 5(3), 1723-1731.

Indrayani, S. A. P., Japa, I. G. N., \& Arini, N. W. (2019). Pengaruh Model Pembelajaran Siklus Belajar Berbasis Tri Hita Karana Terhadap Hasil Belajar Ipa Siswa Kelas V Di Gugus Iv Kecamatan Banjar. Jurnal Pendidikan Multikultural Indonesia, 2(2), 76-86.

Indriyani, P. A., \& Wrahatno, T. (2019). Pengaruh Model Pembelajaran Project-Based Learning (Pjbl) Terhadap Hasil Belajar Siswa Pada Mata Pelajaran Instalasi Penerangan Listrik Di SMKN 3 Jombang. Jurnal Pendidikan Teknik Elektro, 8(3), 459-463.

Kurniasari, R. (2020). Penerapan Model Quantum Teaching Untuk Meningkatkan Hasil Belajar IPS Di Sekolah Dasar. Jurnal Elementaria Edukasia, 3(1), 92-100.

Kurniawan, H. R., Elmunsyah, H., \& Muladi. (2018). Perbandingan Penerapan Model Pembelajaran Project Based Learning Dan Think Pair Share Berbantuan Modul Ajar Terhadap Kemandirian Dan Hasil Belajar Siswa Kelas XI di SMKN 3 Malang. Jurnal Pendidikan, 3(2), 80-85.

Larasati, D. A., Wijaya, U., \& Surabaya, K. (2020). Pengaruh Media Peta Berbasis Konstruktivistik Terhadap Hasil Belajar IPS Siswa Sekolah Dasar. 3(1), 53-63.

Lasmawan, I. W. (2016). Pendidikan IPS. Mediakom Indonesia Press Bali.

Mahdalena, S., \& Sain, M. (2020). Meningkatkan Hasil Belajar Siswa Melalui Penerapan Model Pembelajaran Cooperative Script Pada Matapelajaran Ilmu Pengetahuan Sosial Kelas VA Siswa Sekolah Dasar Negeri 010 Sungai Beringin. Asatiza Jurnal Pendidikan, 1(1), 118-138.

Mayuni, K. R., Rati, N. W., \& Mahadewi, L. P. P. (2019). Pengaruh Model Pembelajaran Project Based Learning (PjBL) Terhadap Hasil Belajar IPA. Jurnal Ilmiah Pendidikan Profesi Guru, 2(2).

Niswara, R., Muhajir, \& Fita, M. A. U. (2019). Pengaruh model project based learning terhadap high order thinking skill. Mimbar PGSD Undiksha, 7(2), 85-90.

Nurjanah, T., \& Esa, Y. M. (2019). Optimalisasi Hasil Belajar IPA Melalui Model Project Based Learning 
Pada Peserta Didik Kelas IV. Prosiding Seminar Nasional PGSD, 1, 59-65.

Pratiwi, I. A., Ardianti, S. D., \& Kanzunnudin, M. (2018). Peningkatan Kemampuan Kerjasama Melalui Model Project Based Learning (PjBL) Berbantuan Metode Edutainment Pada Mata Pelajaran Ilmu Pengetahuan Sosial. Jurnal Refleksi Edukatika, 8(2), 177-182.

Puspitawangi, K. R., Wibawa, I. M. C., \& Pudjawan, K. (2016). Pengaruh Model Pembelajaran Kooperatif Tipe Talking Stick Berbantuan Media Audio Terhadap Hasil Belajar IPS Siswa. Mimbar PGSD, 4(1), 1-12.

Rahayu, H., \& Hartono, H. (2016). Keefektifan Model PBL dan PjBL Ditinjau dari Prestasi, Kemampuan Berpikir Kritis, dan Motivasi Belajar Matematika Siswa SMP. PYTHAGORAS: Jurnal Pendidikan Matematika, 11(1), 1-10.

Rando, A. R., \& Wali, M. (2018). Implementasi Pendidikan Nilai Dalam Pembelajaran IPS Di Sekolah Dasar. Jurnal Pendidikan Ekonomi, 3(2), 74-82.

Santhi, D. G. M., Suarni, N. K., \& Diputra, K. S. (2018). Pengaruh Model Pembelajaran Team Assisted Individualization Berbasis Tri Hita Karana Terhadap Kompetensi Pengetahuan PKn. Jurnal Pendidikan Multikultural Indonesia, 1(2), 73-84.

Saputro, O. A., \& Rayahu, T. S. (2020). Perbedaan Pengaruh Penerapan Model Pembelajaran Project Based Learning ( PjBL) Dan Problem Based Learning ( PBL ) Berbantuan Media Monopoli. Jurnal Imiah Pendidikan Dan Pembelajaran, 4(1), 185-193.

Segara, N. B. (2016). Pentingnya Pemahaman Jati Diri Keilmuan Untuk Meningkatkan Kualitas Pembelajaran IPS. Edunomic, 04(1), 51-59.

Setiadewi, N. P. L., Sujana, I. W., \& Suniasih, N. W. (2019). Kontribusi konsep diri dan motivasi berprestasi terhadap kompetensi pengetahuan ips. Mimbar Ilmu, 24(3), 287-298.

Sucipto, H. (2017). Penerapan Model Project Based Learning untuk Meningkatkan Minat dan Hasil Belajar IPS. Jurnal Pendidikan: Riset \& Konseptual, 1(1), 77-86.

Sunita, N. W., Mahendra, E., \& Lesdyantari, E. (2019). Pengaruh Model Pembelajaran Project Based Learning terhadap Minat Belajar dan Hasil Belajar Matematika Peserta Didik. MIMBAR PGSD Undiksha, 20(1), 127-145.

Surya, A. P., Relmasira, S. C., \& Hardini, A. T. A. (2018). Penerapan Model Pembelajaran Project Based Learning (PjBL) Untuk Meningkatkan Hasil Belajar Dan Kreatifitas Siswa Kelas III SD Negeri Sidorejo Lor 01 Salatiga. Jurnal Pesona Dasar, 6(1), 41-54.

Tiarini, N. P., Dantes, N., \& Yudiana, K. (2019). Pengaruh Model Pembelajaran Problem Based Learning (PBL) Berorientasi Tri Hita Karana Terhadap Hasil Belajar IPA. Jurnal Mimbar Ilmu, 24(3).

Wahyuni, S. (2019). Pengaruh Model Pembelajaran Project Based Learning Terhadap Kemampuan Pemahaman Konsep Mahasiswa Mata Kuliah Kapita Selekta Matematika Pendidikan Dasar Fkip Umsu. Jurnal EduTech, 5(1), 84-88.

Wibawa, I. B., Suadnyana, I. N., \& Asri, I. G. A. A. S. (2018). Pengaruh Model Pembelajaran Make A Match Berbantuan Media Audio Visual Terhadap Kompetensi Pengetahuan IPS. Jurnal Ilmiah Sekolah Dasar, 2(2), 136-143.

Wijanarko, A. G., Imam, S. K., \& Marwoto, P. (2017). Keefektifan Model Project Based LearningTerbimbing untuk Meningkatkan Keterampilan Proses Sainsdan Hasil Belajar IPA. Journal of Primary Education, 6(2), 120-125. 